\title{
Obesity - a risk factor for increased COVID-19 prevalence, severity and lethality (Review)
}

\author{
DEMETRIOS PETRAKIS ${ }^{1}$, DENISA MARGINA ${ }^{2 *}$, KONSTANTINOS TSAROUHAS $^{3 *}$, \\ FOTIOS TEKOS $^{4}$, MIRIANA STAN ${ }^{5}$, DRAGANA NIKITOVIC ${ }^{6}$, \\ DEMETRIOS KOURETAS ${ }^{4}$, DEMETRIOS A. SPANDIDOS ${ }^{7}$ and ARISTIDIS TSATSAKIS ${ }^{1}$
}

\begin{abstract}
${ }^{1}$ Laboratory of Toxicology, Medical School, University of Crete, 71409 Heraklion, Greece; ${ }^{2}$ 'Carol Davila' University of Medicine and Pharmacy, Faculty of Pharmacy, Department of Biochemistry, 020956 Bucharest,

Romania; ${ }^{3}$ Department of Cardiology, University Hospital of Larissa, 41110 Larissa; ${ }^{4}$ Department of

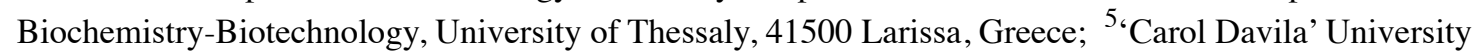
of Medicine and Pharmacy, Faculty of Pharmacy, Department of Toxicology, 020956 Bucharest, Romania;

${ }^{6}$ Laboratory of Histology-Embryology, School of Medicine, University of Crete, 71003 Heraklion;

${ }^{7}$ Laboratory of Clinical Virology, Medical School, University of Crete, 71110 Heraklion, Greece
\end{abstract}

Received April 6, 2020; Accepted May 5, 2020

DOI: $10.3892 / \mathrm{mmr} .2020 .11127$

\begin{abstract}
Coronaviruses (CoVs), enveloped positive-sense RNA viruses, are a group of viruses that cause infections in the human respiratory tract, which can be characterized clinically from mild to fatal. The severe acute respiratory syndrome coronavirus 2 (SARS-CoV-2) is the virus responsible. The global spread of COVID-19 can be described as the worst pandemic in humanity in the last century. To date, COVID-19 has infected more than 3,000,000 people worldwide and killed more than 200,000 people. All age groups can be infected from the virus, but more serious symptoms that can possibly result in death are observed in older people
\end{abstract}

Correspondence to: Professor Denisa Margină, 'Carol Davila' University of Medicine and Pharmacy, Faculty of Pharmacy, Department of Biochemistry, TraianVuia 6, 020956 Bucharest, Romania

E-mail: denisa.margina@umfcd.ro; denisa.margina@gmail.com

Professor Aristidis Tsatsakis, Laboratory of Toxicology, Medical School, University of Crete, Voutes, 71409 Heraklion, Greece

E-mail: tsatsaka@uoc.gr

*Contributed equally

Abbreviations: CDC, Center for Disease Control and Prevention; AT1R, angiotensin receptor 1; AT2R, angiotensin receptor 2; NFAT5, nuclear factor of activated $\mathrm{T}$ cells 5; ARDS, acute respiratory distress syndrome; RLA, reactive lipid aldehydes; MDA, malondialdehyde; 4-HNE, 4-hydroxy nonenal; CVD, cardiovascular desease; SOD, superoxide dismutase; GPX, glutathione peroxidase; Prdx, peroxiredoxin; Cat, catalase; ARE, antioxidant response element; RAAS, renin-angiotensin-aldosterone system

Key words: COVID-19, obesity, lipotoxicity, inflammation, oxidative stress, immune response and those with underlying medical conditions such as cardiovascular and pulmonary disease. Novel data report more severe symptoms and even a negative prognosis for the obese patients. A growing body of evidence connects obesity with COVID-19 and a number of mechanisms from immune system activity attenuation to chronic inflammation are implicated. Lipid peroxidation creates reactive lipid aldehydes which in a patient with metabolic disorder and COVID-19 will affect its prognosis. Finally, pregnancy-associated obesity needs to be studied further in connection to COVID-19 as this infection could pose high risk both to pregnant women and the fetus.

\section{Contents}

1. Introduction

2. Obesity and the metabolic link to COVID-19

3. Age and obesity

4. Obesity and inflammation

5. Obesity and immune response

6. Lipotoxicity and obesity

7. Oxidative stress, reactive oxygen species, lipid peroxidation

8. COVID-19 and obesity

9. COVID-19 and the obesity paradox

10. Pregnancy, obesity and COVID-19

11. Conclusion

\section{Introduction}

The current SARS-CoV-2 pandemic challenges the health systems across the world to an unprecedented degree (1); the scientific community was put to a test in order to evaluate the risk factors associated with the viral response, since the most sensitive patients in respect to the respiratory response to the pathogen are those in a prerequisite unbalanced health condition. 
Obesity is one of the most important conditions that increases exponentially the mortality risk of the SARS-CoV-2 patients (2); the Center for Disease Control and Prevention (CDC) determined the most important groups with higher risk for severe illness, noting that, besides obesity, asthma, chronic lung disease, diabetes, serious heart conditions, chronic kidney disease, severe obesity, age 65 years and older, people in nursing homes or long-term care facilities, immune-compromised, and liver disease patients are the most vulnerable to the complications. Examining the respective list we can conclude that most of the high risk group patients have conditions associated frequently or consequences of obesity (diabetes, heart conditions, asthma, etc.) (3-5).

The strong correlation between obesity and the complications of viral infections was previously pointed out, for the influenza virus as well as for the previous corona-viruses causing wide spread infections (SARS, MERS). This association is important when analyzing results, since there is an increased genetic similarity between SARS-CoV-2 (determining COVID-19), SARS-CoV (80\%) and MERS-CoV $(50 \%)(6)$. Studies show that obese patients are at higher risk of hospital admission regardless of their viral status and also, obese patients are at higher risk of hospitalization compared to normo-ponderal ones, when affected by influenza $(7,8)$.

\section{Obesity and the metabolic link to COVID-19}

Literature data state that there is a direct metabolic link between the state of inflammation (such as the one associated with diabetes and metabolic syndrome) and the "cytokine storm' contributing to the respiratory decline of COVID-19 patients. The entry of the virus to the cell is mediated by the ACE2 ectoenzyme located at the cell surface in the lungs and by the serine protease TMPRSS2; thus, the correlation with the renin-angiotensin system is obvious. Indeed, ACE1 activity is increased and ACE2 inhibited; while angiotensin II activates angiotensin receptors 1 and 2 (AT1R, AT2R) mediating a pro-inflammatory response, and a consequent increase of vascular permeability. Importantly, this metabolic imbalance is aggravated by pre-existing diabetes or hypertension, usual consequences of obesity $(9,10)$. Moreover, some drugs frequently used for treatment of obese patients complications (such as antihypertensives, statins, thiazolidinediones) have the tendency to up-regulate ACE2, thus increasing the viral up-take (11-13). Previous preclinical studies in an animal model showed that the association of diabetes with MERS-CoV dampened the ability of the body to engage an effective immune response and induced a poor recovery after illness (14).

The disease burden of obesity is obvious in hospitalized COVID-19 patients and has strong relationship with the development of obese-related major and lethal complications. Obesogenic comorbidities $(15,16)$ have become major health problems in hospitalized patients including increased insulin resistance (17-20) and type 2 diabetes (21), fatty liver diseases $(22,23)$, vascular inflammation and coronary heart disease $(24,25)$, immune diseases $(26)$, risk of cerebral ischemia and brain injury (27), atherosclerotic vascular disease and myocardial infarction (28) as well as cancers (29). Adipose tissue and adipocytes produce leptin and other molecules that affect the cardiovascular function. The production of these substances is perpetrated through distinct endocrine, autocrine and paracrine mechanisms and believed to lead to cytokine-mediated inflammatory changes in the liver and systemic inflammation and atherosclerosis (30-33).

Smethers and Rolls (34) reported that, in obese adults, the correlation between unhealthy eating patterns or uncontrolled eating management and immune deficiency is highly complex. Systematic reviews $(35,36)$, research studies (37) and meta-analyses (38) have documented that high-energy diets are a risk factor for weight gain. Nutritional patterns collectively termed as 'Western diet', include trans- and saturated high-fats and cholesterol, high-protein, high-sugar, excess salt intake, low in complex carbohydrates, fiber, micronutrients such as vitamin D (39) and are all associated with impaired inflammatory pathways (40-47). Frequent consumption of processed, 'fast foods' or foods contaminated with pesticide residues predispose individuals to inflammation through the increased uptake of lipopolysaccharide from microbes in the gut because of increased gut leakiness (48) as well as promote obesity and metabolic syndrome (15). Furthermore, unhealthy diet has been correlated to autoimmune pathology such as multiple sclerosis (49), rheumatoid arthritis (50), inflammatory bowel disease (51), systemic lupus erythematosus (52) and psoriasis, through specific deregulations of T cells (Treg) that particularly promote leptin (53) and TH17-biased immunity, partly dependent on increased IL-6 (54). Importantly, excess dietary salt intake is associated with obesity (55), hypertension, cardiovascular disease and stroke (56), through the enhancement of pathogenic TH17 cells (57) as well as p38/MAPK and nuclear factor of activated T cells 5 (NFAT5) activation (58), due to cellular response to hyperosmotic environments (59).

The pulmonary tissue is the most sensitive human tissue in intensive care unit (ICU) COVID-19 patients. Systemic hypoxia due to reduced pulmonary functions, increased adipokines and cytokines, gut (60) and pulmonary (61) microbiome alterations (62), cardiopulmonary, vascular and epithelial complications due to chronic obstructive pulmonary disease (63) are cofactors associated with critical illness among hospitalized patients with COVID-19 disease reported in Zhanjiang province (64) and Jiangsu province, China (65) as well as in New York City, USA (66). Petrilli et al pointed out that, in COVID-19 ICU patients, the highest risks are exhibited by those aged $\geq 75$ years, body mass index $(\mathrm{BMI})>40$ and heart failure. Moreover, strong critical illness parameters were admission oxygen saturation $<88 \%$, d-dimer $>2,500$, ferritin $>2.500$ as well as C-reactive protein $(\mathrm{CRP})>200$.

\section{Age and obesity}

Aging seems to present with a great variety of patterns and unique sets of obesity and age-related disease. Among older adults, independent of their BMI, blood pressure and blood lipid concentrations (67), decline in immune function is observed (known as immune-senescence) leading to increased susceptibility and exhibiting more serious complications as compared to younger individuals; reflecting the deterioration of function in both the acquired and innate immune systems $(20,45,68)$. In elderly, most cells produce cytokines/ chemokines/adipokines and soluble mediators of inflamma- 


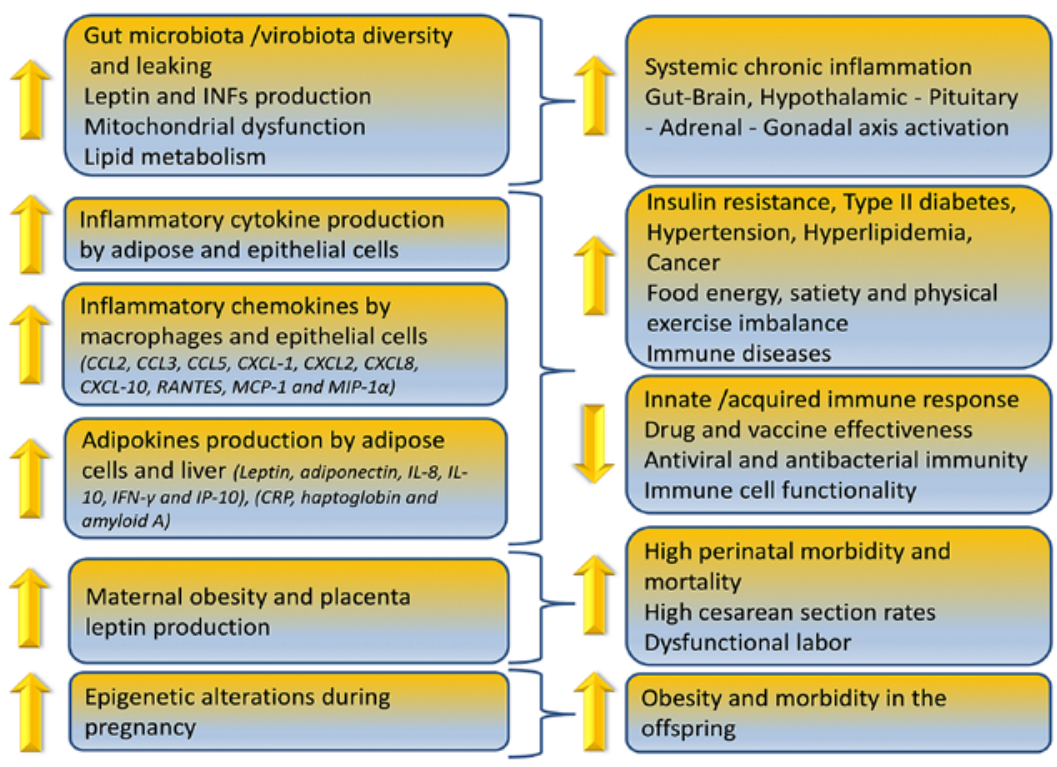

Figure 1. Influence of obesity on the immune system.

tion due to inflammation-related gene expression by ROS induced lipid oxidation-derived products and formation of lipid droplets within the monocytes/macrophages (69). Ageing is also associated with a multi-factorial decrease of $\mathrm{T}$ cell function and number, $\mathrm{T}$-cell subset composition and functional capacity, fewer naive $\mathrm{T}$ cells, more memory cells in the circulation, thymic involution and decreased thymic output and naive $\mathrm{T}$ cells as well as increased memory cells in the circulation (70). Furthermore, modifications of immunoglobulin levels, micronutrient deficiencies (71) and biological dysfunctions including lymphocyte proliferation and cytokine production, thus increasing inflammation, as well as hospitalization and death have been documented (72).

In March 2020 (1) a review was published on the 2019 outbreak (COVID-19) supporting that 'COVID-19 lethality is proving to be higher than previous epidemics on account of international travel density and immune naivety of the population'. In obese COVID-19 patients, the adipose tissue interacts with the immune system facilitating the severity and lethality of the disease through biochemical, molecular, cellular as well as immune interplay.

The World Health Organization (WHO) has characterized both the COVID-19 outbreak and obesity 'epidemic' as international public health emergencies. Global clinical and epidemiological observations confirm that CoVs can cause more severe symptoms and complications in people with obesity-related conditions. Indeed, Wu et al (4) established the correlation between obesity-induced immune deficiency and COVID-19 adverse outcomes.

\section{Obesity and inflammation}

Immunologically, obesity is characterized as a chronic sub-clinical inflammatory morbid entity which can impact the immune responses to infectious diseases through direct, indirect and epigenetic $(73,74)$ mechanisms. Evans et al $(75)$ described various fat tissue-associated cytokines (adipokines) that are produced and released in proportion to the amount of visceral adipose tissue in the body. Serum amyloid-A is an adipokine secreted by adipocytes, that can act directly on macrophages to increase their production of inflammatory cytokines such as tumor necrosis factor (TNF)- $\alpha$, interleukin (IL)-1, and IL-6, and resistin (22,23,75). Indeed, Alam et al (76) reported in detail that the majority of respective adipokines are inflammatory mediators such as IL-8, PAI-1, MCP-1, IL-6, IL-1Ra, TNF- $\alpha$, sTNFRII, and IL-18.

In addition, IL-8, IL-10, interferon gamma (IFN- $\gamma$ ) and inducible protein 10 (IP-10 or CXCL10) have been shown to be associated with excessive body weight (77). Obesity-induced adipokine production such as leptin /adiponectin ratio increases insulin resistance in type 2 diabetes, resulting in inability to feel and detect satiety leptin in the arcuate nucleus of mediobasal hypothalamus (78). Moreover, adverse effects are evident, despite high energy stores, on hunger, food energy use, physical exercise and energy balance as well as on hippocampus-mediated deficit in learning and memory functions (79). Furthermore, the prolonged IFN responses during persistent chronic inflammation and obesogenesis comprise reciprocal causality between virus susceptibility and obesity (80). Additional epigenetic signatures in obesity are likewise altered including methylation and/or histone acetylation levels in genes involved in specific and general metabolic processes, altering thus, the metabolic phenotype of the offspring (81-83). Although no specific therapy exists to block the effects of these factors, recognizing the high risk and anticipating inflammation-associated complications of adipokine release is an important part of optimal patient management.

\section{Obesity and immune response}

Obesity can reduce immune cell functionality, induce gut microbiome/virome imbalance, inflammatory cytokine phenotype and increase antiviral, antimicrobial and anticoagulant resistance as depicted in Fig. 1. In overweight children, anti-tetanus IgG antibodies were significantly lower compared 


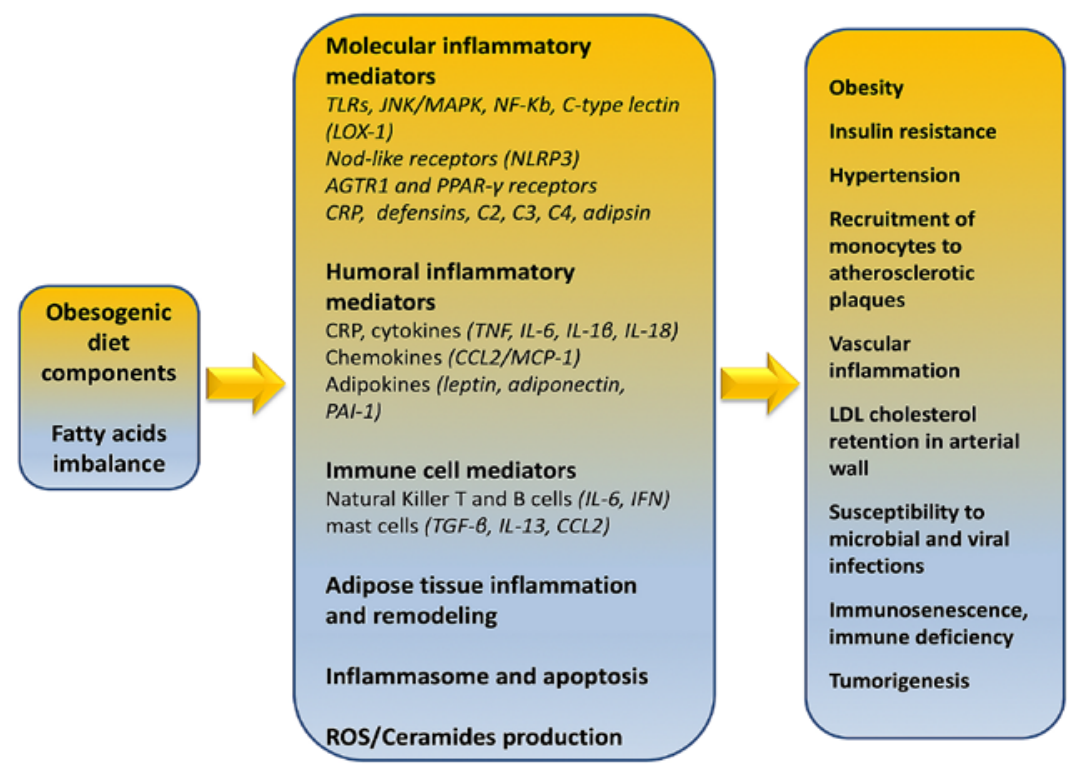

Figure 2. Obesity-related immune/metabolic mediators and effects.

to normal weight controls due to the chronic low grade inflammation expressed by the higher levels of IL-6 (84). Similarly, researchers reported in a 2019 study that reduction or elimination of food in overweight/obese adults can lead to a decreased IgG concentration over time (85).

The mechanisms involved in increased risk for higher COVID-19 prevalence and mortality in obese are correlated with specific fat-resident regulatory $\mathrm{T}$ cells (86) (Treg) and particularly promotion of $\mathrm{T}_{\mathrm{H}} 17$ (T-cell sub-lineage)-biased immunity $(87,88)$. Indeed, these processes are partly dependent on increased IL-6, as well as IL-23/IL-17, other inflammatory obesity-associated plasma cytokine expression such as TNF- $\alpha$, transforming growth factor (TGF), pro-inflammatory cytokine macrophage migration inhibitory factor and macrophage inflammatory protein-1 $\alpha$ (89). Furthermore, in this mechanism increased CRP levels (90) and disrupted tight junctions in pulmonary epithelia (91) have also been implicated. Additionally, Ahmed and Gaffen (92) argued that 'obesity selectively promotes expansion of the Th17 T-cell lineage, exacerbating immune diseases in specific organs in obese individuals, such as brain and gut, according to the results of new experimental and human studies. Th17 cells are also associated with autoimmune disease such as multiple sclerosis, rheumatoid arthritis, and psoriasis (93), but also glomerulonephritis, asthma, and pandemic H1N1 influenza virus (94).

Strissel et al (95) demonstrated that adipose tissue inflammation as well as the resistance to insulin action in adipocytes are accelerated by a high fat diet. This induces the mobilization of $\mathrm{T}$ cells (predominantly $\mathrm{CD}^{+}$and $\mathrm{CD}^{+}$) to adipose tissue and associated increased synthesis of IFN $\gamma$ thus, contributing to the local inflammatory responses (Fig. 2). Inflammatory $\mathrm{T}$ helper cells secreting cytokines including IL-1 $\beta$, IL-6, IL-8, IL-10, TNF- $\alpha$, granulocyte- and macrophage-colony stimulating factor (GM-CSF) are present both in obese phenotype and COVID-19 patients, affecting prognosis, pathogenesis and fatality.

According to Zhou et al (96), COVID-19 entry into the cell leads to over-production of inflammatory cytokines.
Importantly, in ICU patients infected with SARS-CoV-2, the expression of specific proteins increased significantly, suggesting an exhausted status of T cells. COVID-19 ICU patients with severe pneumonia showed correlated higher percentage of $\mathrm{GM}-\mathrm{CSF}^{+}$and $\mathrm{IL}-6^{+} \mathrm{CD} 4^{+} \mathrm{T}$ cells. The inflammatory signature of monocytes $\left(\mathrm{CD} 14^{+} \mathrm{CD} 16^{+}\right.$with high expression of IL-6) is similar in ICU COVID-19 patients and obese adults with inflammatory phenotype. Therefore, activated immune cells may enter the pulmonary circulation in large numbers and exert a damaging role especially in obese COVID-19 patients with severe pulmonary syndrome caused by pathogenic GM-CSF${ }^{+}$Th1 cells and inflammatory $\mathrm{CD}_{14}{ }^{+}$and $\mathrm{CD} 16^{+}$monocytes. Indeed, a cytokine-abundant environment, aberrant pathogenic Th1 cells, inflammatory $\mathrm{CD}_{14}{ }^{+}, \mathrm{CD}_{16}{ }^{+}$monocytes, the high expression of IL- 6 and intense inflammatory monocytes infiltration, to pulmonary circulation, accelerate the inflammation and affect pulmonary immune-pathology leading to deleterious clinical manifestations, lung functional disability and even acute mortality.

On April 15, 2020, the Centers for Disease Control and Prevention (CDC), based on currently available information and clinical expertise, advised that older adults and people of any age who have serious underlying medical conditions, including obesity with a BMI of 40 or above, might be at higher risk for complications and severe illness from COVID-19. In this report, emphasis is given on ascertainment that severe obesity increases the risk of acute respiratory distress syndrome (ARDS) (3).

Obesity, increased food intake, nutrient/energy imbalance affect in a bidirectional way the immune deficiency, especially in vulnerable populations. Patients with type 2 diabetes and those with metabolic syndrome (pre-diabetes) may be up to ten times more likely to die when they become ill with COVID-19 (9). The mortality rate for young people who had to be admitted to a hospital with severe respiratory illness due to COVID-19 was approximately $2 \%$, but this increased to $14 \%$ for the most vulnerable such as COVID-19 patients with obesity and related co-morbidity (97). For autoimmune 


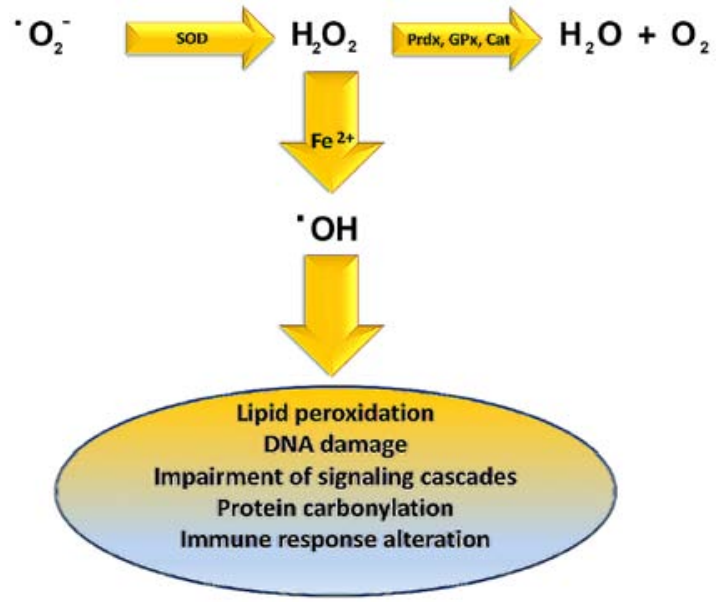

Figure 3. Impact of hydroxyl radicals on cellular components. SOD, superoxide dismutase; Prdx, peroxiredoxin; GPx, glutathione peroxidase; Cat, catalase.

diseases, such as systemic lupus erythematosus, systemic vasculitis and rheumatoid arthritis, treatment may include drugs including methotrexate and hydroxychloroquine (Plaquenil) that suppress the immune system to treat the disease and symptoms making immune-compromised patients more vulnerable to COVID-19 infection (98).

Foods may have calories, but do not contain vitamins, minerals, antioxidants etc., indicating that increased calorie intake, in relation to nutrient intake, is the main reason behind the immunodeficiency today. For example, even short-term severe vitamin D deficiency (99) may directly promote hypertension and impacts on renin-angiotensin system components that could contribute to target-organ damage (100). Nutrient deficiencies are highly prevalent in the United States (and elsewhere), increasing much of the consequent risk of premature aging, chronic disease and COVID-19 prevalence and mortality due to acceleration of the risk associated with aging (101).

In addition low dietary antioxidant intake (102), occupational exposures (103) and increased genetically modified foods (104) including cotton seed/canola seed/corn oil, eggplant, fruits and vegetables e.g., papaya, potatoes, tomatoes, lettuce may enhance immune system deficiency (105).

\section{Lipotoxicity and obesity}

Lipotoxicity is a condition, induced by the aggregation of intermediate lipids to non-fatty tissue, which leads to cell malfunction and death (106). Tissues that are usually affected include kidneys, liver, heart, and skeletal muscle. Lipotoxicity is believed to play a role in heart failure, obesity and diabetes and is estimated to affect approximately $25 \%$ of the adult American population $(20,45,107,108)$.

Under physiological conditions, there is a balance between cellular lipid production and their oxidation or transport. However, this balance might be disrupted when the cells are lipotoxic, that is, when an imbalance between the amount of cellular lipids produced and the amount consumed is evident. Thus, upon fatty acids entry to cells, conversion to various types of storage lipids is initiated. Triacylglycerol (TG), consisting of a glycerin molecule bound to three fatty acids, is established as the safest type of intracellular lipid storage. Apart from TG, fatty acids can be converted to fatty acyl-CoAs, ceramides and diacylglycerol. Importantly, these molecules were shown to induce lipotoxicity when found in high concentrations and can inflict damage to cells (109).

It is not well-established whether lipotoxicity is related to genetic or non-genetic causes, but it is not considered to be a single-gene disease. Opinions which argue that obesity can either attenuate or facilitate lipotoxicity exist. Indisputably, a high-fat diet increases the risk for this pathological condition. Importantly, individuals with high number of lipotoxic cells appear to be resistant to both insulin and leptin (110).

\section{Oxidative stress, reactive oxygen species, lipid peroxidation}

Initially the term oxidative stress was defined as the imbalance between pro-oxidants and antioxidants in favor of the former (111). Over the years, this definition is based on new data, and oxidative stress is now considered a disorder of the redox signaling (112).

Lipid peroxidation is caused by hydroxyl radical $(\mathrm{OH} \cdot)$ derived from elevated superoxide anion levels $\left(-\mathrm{O}_{2} \cdot\right)$ (Fig. 3). In turn, hydroxyl radical causes the formation of LOOH. Finally, a variety of reactive lipid aldehydes (RLA) such as malondialdehyde (MDA) and 4-hydroxynonenal (4-HNE) are created, with the ability to modify proteins through protein carbonylation $(113,114)$. Normally phase I and phase II enzymes would detoxify RLA products, but in individuals exhibiting metabolic syndrome, RLAs accumulate causing damage to cells and their membranes. These alterations have been associated with inflammation and various pathologies including obesity, neurodegenerative disease, asthma, cardiovascular desease (CVD), type II diabetes, and cancer (115-124).

Oxidative stress, as mentioned above, leads to increased free fatty acids concentration in $\beta$-type pancreatic cells, enhanced insulin secretion, type II diabetes and cell death, through the exit of cytochrome c from the mitochondria and the activation of caspase 3 (113). One strategy for protection against these detrimental effects has been proposed in a study by Zhu et al (125) in which the effects of perilipin 5 were examined. Perilipin 5 activates the PI3K/Akt path as well as ERK signaling which activates NRF2 $\beta$-type pancreatic cells. Subsequently, NRF2 enters the nucleus and as a transcriptional factor activates the antioxidant response element (ARE) that enhances the transcription of down-stream antioxidant enzymes. As a result, $\beta$-type pancreatic cells exhibit increased glutathione levels and decreased reactive oxygen species levels. The above signaling pathway thus, enhances $\beta$-type pancreatic cell protection, defends them from apoptosis and facilitates the execution of the normal function of these cells.

\section{COVID-19 and obesity}

Obesity has been linked to increased susceptibility to infections (126). In addition, a very important field of research suggests that various types of viruses utilize fatty tissue as a reservoir, including adenovirus Ad-36, influenza A virus as well as HIV (127). In this sense, the COVID-19 tissue and 
cellular localization may be correlated to fatty tissue (128). The association of obesity with elevated mortality rates compared to non-obese people who have a common virus (H1N1) has been reported (129-133). Another study in 30 people with COVID-19 showed that patients with BMI 27.0 2.5 exhibit the disease with more severe symptoms as compared to patients with BMI 22.0 \pm 1.3 (134). Finally, an analysis of BMI correlation in cohort of COVID-19 patients showed that non-survivors who were $15.18 \%$ of the total participants, in the respective study had BMI $>25$ at a rate of $88.2 \%$. On the contrary only $18.9 \%$ of survivors, had BMI $>25$ (135).

Clinical reports of patients infected with SARS-CoV-2 show that several parameters associated with infection as well as the severity of the disease (i.e., older age, hypertension, diabetes, cardiovascular disease) are correlated to viral invasion induced ACE2 down-regulation. Importantly, angiotensin converting enzyme-2 (ACE2) receptors mediate the entry of SARS-CoV, NL63 and SARS-COV-2 into the cell (136), particularly in type 2 pneumocytes and macrophages, as well as angiotensin II degradation to angiotensin 1-7 via the $\mathrm{ACE} \rightarrow$ Angiotensin II $\rightarrow$ Angiotensin II receptor type 1 or AT1 receptor axis (137). Structural, allelic or genetic variations in the SARS-CoV-2 spike protein and genetic or allelic variations of the host receptor ACE2 including rs73635825 (S19P) and rs143936283 (E329G) lead to the cross-species transmission of the virus. The specific modifications have been found to significantly contribute to the susceptibility and/or resistance against the viral infection (138). Thus, the resulting ACE2 deficiency upon viral invasion may enhance the dys-regulation between the 'adverse' $\mathrm{ACE} \rightarrow$ Angiotensin $\mathrm{II} \rightarrow \mathrm{AT} 1$ receptor axis and the 'protective' ACE2 $\rightarrow$ Angiotensin 1-7 $\rightarrow$ Mas receptor signaling. In the lungs, decreased angiotensin 1-7 and G-protein coupled Mas receptor binding, enhances the severity of vasoconstriction, fibrosis, inflammation, thrombosis and pulmonary damage including edema and permeability triggered by local angiotensin II hyperactivity unopposed by angiotensin 1-7 (139).

Although the association between obesity and heart disease is well-established, underlying pathophysiological processes remain elusive, and it is unclear whether cardiomyopathy in obese patients is due to increased deposition of adipose tissue itself or due to the effects of obesity-associated comorbidities, including hypertension, metabolic syndrome, and diabetes. In obesity, the heart undergoes structural remodeling and functional alterations leading to obesity-associated cardiomyopathy due to interstitial fibrosis, cardiomyocyte hypertrophy, and cardiac steatosis (140) Oxidative stress, natriuretic peptides, endothelin-1, advanced glycation end products, induction of TGF $\beta$, increased mean arterial pressure in elderly through the activation of the renin-angiotensin-aldosterone system (RAAS) (141), Rho-kinase signaling, leptin-mediated actions, up-regulation of matricellular proteins (such as thrombospondin 1), are molecular mechanisms associated with these processes especially in obese adults (142). Furthermore, the sleep apnea/obesity hypoventilation syndrome, as well as respective coexisting neurohormonal and metabolic alterations, diabetes (143), insulin resistance and long-term inflammatory adipocyte-derived factors directly influence the pro-inflammatory signaling in the heart (144).

The above data are very important as it seems that lipotoxicity and obesity are directly related to viral infections as well as to the challenges in combating this infection, as shown by the increased need of severely obese patients for ventilator support. The fact that in the western world general population exhibits much higher rates of obesity argues that these countries need to be prepared as regarding intensive care units (ICU) and ventilator devices. Finally, it is important for obese individuals to take all the preventive actions proposed by the WHO to minimize the chances of becoming infected with COVID-19 (145,146).

\section{COVID-19 and the obesity paradox}

It is important to note that RAAS and ACE2 are expressed in adipose tissue and that angiotensin II can be released from fat tissue during periods of increased sympathetic nervous system activity with complex interactions linking central RAAS with adipose tissue RAAS (147).

COVID-19 however, seems to challenge the obesity paradox (148) as in various pathologies connected with high levels of inflammation including heart failure, kidney failure and ARDS being obese seems to offer a dose of protection and moderate obese patients tend to present lower mortality. Indeed, in mechanically ventilated adults with acute lung injury, O'Brien et al (149), in a retrospective study in 1,488 patients, determined that patients with lower body mass index (BMI) were associated with higher mortality as compared to obese patients. In the case of ARDS, it was hypothesized that clinicians tended to admit more readily obese patients to ICU, regarding them as more vulnerable and needing extra care (150). The said obesity paradox was also found to exist for patients with pneumonia according to a meta-analysis of ten cohort studies on mortality $(151,152)$. Mechanistically, other researchers have expressed the opinion that obesity induces a type of preconditioning to inflammatory cues, constituting obese patients more resistant to the high influx of inflammatory cytokines under ARDS or heart failure conditions.

Indeed, it has been suggested in cardiovascular disease patients that the aforesaid obese may reflect the biological properties of adipose tissue (153). Indeed, not all obese people present inflammation; thus, the terms of metabolically healthy and unhealthy obesity are used with metabolically unhealthy obesity being linked to increased visceral/abdominal fat (76).

Obesity was rarely mentioned in early clinical reports evaluating the clinical risk factors for SARS-CoV-2 infection. Novel data from a single center retrospective study confirm that obesity had a high frequency among patients admitted in intensive care for SARS-CoV-2 requiring invasive mechanical ventilation and that disease severity increased with BMI (154). Indeed, a very recent report on a large sample of patients younger than 60 years tested positive for COVID-19, correlated higher BMIs values with increased probability for admission to critical care (155).

\section{Pregnancy, obesity and COVID-19}

Importantly, overweight, pre-pregnancy obese and obese pregnant women are at increased risk for both morbidity and mortality from CMV (156), including all recorded influenza pandemics, 1918 (157), 1957 (158), and 2009 (159), Varicella Zoster (160), Listeria monocytogenes (161), malaria (162), 
as well as SARS (163). Moreover, the highest mortality risk for these pregnant women was correlated to acute cardiopulmonary conditions presenting in the second and third trimesters (164). Furthermore, the above mentioned pathological conditions were associated with adverse pregnancy outcomes, including preterm birth and fetal death (165).

Maternal burden of coronavirus infection may have significant implications for neonatal immune ontogeny, as high maternal viremia has been associated with significantly lower $\mathrm{CD}^{+}{ }^{+} \mathrm{T}$-cell count in uninfected progeny. Increased levels of pro-inflammatory cytokines produced by placental cells can negatively affect infant innate cytokine responses in early life, pregnancy outcomes and facilitate mother-to-child transmission of coronavirus in the infant. Indeed, increased placenta leptin production affects uterine contractility playing a role in the dysfunctional labor process associated with maternal obesity, and the resultant high cesarean section rates (166).

Pregnancy immune phenotype may be correlated with the SARS-COV-2 prevalence in pregnant women. Both xenobiotics and enveloped viruses such as SARS-COV-2 induce immune-suppression (167) characterized by significant increases in blood phagocytes, placental DCs and immature monocyte-derived DCs, decreases in the number and activity of NK and T cells (168), and inhibition of TH1 responses from maternal-fetal $\mathrm{TH} 2$ cytokine cocktail especially IL-1 $\beta+$ IL- $6+$ TNF- $\alpha+\alpha$-defensins (169) shifting toward Th2 immunity (170), inefficacy of adaptive/inflammatory immunity in the later stages of pregnancy as well as membrane permeabilization to SARS-COV-2 entry (171).

\section{Conclusion}

Obesity is a medical condition with complex pathophysiology, comprising various mechanisms, which now emerges as a significant risk factor for COVID-19. Targeted epidemiological studies specifically oriented in order to reveal the impact of obesity in COVID-19 severity and mortality rates are needed in order to determine specific therapeutic strategies for obese patients.

\section{Acknowledgements}

Not applicable.

\section{Funding}

No funding was received.

\section{Availability of data and materials}

Not applicable.

\section{Authors' contributions}

Conceptualization: DP, DM, DK, DAS, AT; writing (original draft preparation): DP, DM, KT, FT; writing (review and editing): DP, DM, KT, FT, DN, DK, DAS, AT; figure preparation: DP, DM, FT; supervision: DM and AT; all authors have read and agreed to the published version of the manuscript.

\section{Ethics approval and consent to participate}

Not applicable.

\section{Patient consent for publication}

Not applicable.

\section{Competing interests}

DAS is the Editor-in-Chief for the journal, but had no personal involvement in the reviewing process, or any influence in terms of adjudicating on the final decision, for this article. The other authors declare that they have no competing interests.

\section{References}

1. Docea AO, Tsatsakis A, Albulescu D, Cristea O, Zlatian O, Vinceti M, Moschos SA, Tsoukalas D, Goumenou M, Drakoulis N, et al: A new threat from an old enemy: Re emergence of coronavirus (Review). Int J Mol Med 45: 1631-1643, 2020.

2. Goumenou M, Sarigiannis D, Tsatsakis A, Anesti O, Docea AO, Petrakis D, Tsoukalas D, Kostoff R, Rakitskii V, Spandidos DA, et al: COVID 19 in Northern Italy: An integrative overview of factors possibly influencing the sharp increase of the outbreak (Review). Mol Med Rep 22: 20-32, 2020.

3. Centers for Disease Control and Prevention (CDC): Coronavirus Disease 2019 (COVID-19). People who are at higher risk for severe illness. https://www.cdc.gov/coronavirus/2019-ncov/ need-extra-precautions/groups-at-higher-risk.html. Accessed April 15, 2020.

4. Wu C, Chen X, Cai Y, Xia J, Zhou X, Xu S, Huang H, Zhang L, Zhou X, Du C, et al: Risk factors associated with acute respiratory distress syndrome and death in patients with coronavirus disease 2019 pneumonia in Wuhan, China. JAMA Intern Med: Mar 13, 2020 (Epub ahead of print).

5. Zhou F, Yu T, Du R, Fan G, Liu Y, Liu Z, Xiang J, Wang Y, Song B, Gu X, et al: Clinical course and risk factors for mortality of adult inpatients with COVID-19 in Wuhan, China: A retrospective cohort study. Lancet 395: 1054-1062, 2020.

6. Muniyappa R and Gubbi S: COVID-19 pandemic, coronaviruses, and diabetes mellitus. Am J Physiol Endocrinol Metab 318: E736-E741, 2020.

7. Moser JS, Galindo-Fraga A, Ortiz-Hernández AA, Gu W, Hunsberger S, Galán-Herrera JF, Guerrero ML, Ruiz-Palacios GM and Beigel JH; La Red ILI 002 Study Group: Underweight, overweight, and obesity as independent risk factors for hospitalization in adults and children from influenza and other respiratory viruses. Influenza Other Respir Viruses 13: 3-9, 2019.

8. Yuen KS, Ye ZW, Fung SY, Chan CP and Jin DY: SARS-CoV-2 and COVID-19: The most important research questions. Cell Biosci 10: 40, 2020.

9. Bornstein SR, Dalan R, Hopkins D, Mingrone G and Boehm BO: Endocrine and metabolic link to coronavirus infection. Nat Rev Endocrinol: Apri 2, 2020 (Epub ahead of print).

10. Drucker DJ: Coronavirus infections and type 2 diabetes-shared pathways with therapeutic implications. Endocr Rev 41: bnaa011, 2020.

11. Zhang W, Xu YZ, Liu B, Wu R, Yang YY, Xiao XQ and Zhang $X$ : Pioglitazone upregulates angiotensin converting enzyme 2 expression in insulin-sensitive tissues in rats with high-fat diet-induced nonalcoholic steatohepatitis. ScientificWorldJournal 2014: 603409, 2014.

12. Tikoo K, Patel G, Kumar S, Karpe PA, Sanghavi M, Malek V and Srinivasan K: Tissue specific up regulation of ACE2 in rabbit model of atherosclerosis by atorvastatin: Role of epigenetic histone modifications. Biochem Pharmacol 93: 343-351, 2015.

13. Romaní-Pérez M, Outeiriño-Iglesias V, Moya CM, Santisteban P, González-Matías LC, Vigo E and Mallo F: Activation of the GLP-1 receptor by liraglutide increases ACE2 expression, reversing right ventricle hypertrophy, and improving the production of SP-A and SP-B in the lungs of type 1 diabetes rats. Endocrinology 156: 3559-3569, 2015. 
14. Kulcsar KA, Coleman CM, Beck SE and Frieman MB: Comorbid diabetes results in immune dysregulation and enhanced disease severity following MERS-CoV infection. JCI Insight 4: 131774, 2019.

15. Petrakis D, Vassilopoulou L, Mamoulakis C, Psycharakis C, Anifantaki A, Sifakis S, Docea AO, Tsiaoussis J, Makrigiannakis A and Tsatsakis AM: Endocrine disruptors leading to obesity and related diseases. Int J Environ Res Public Health 14: E1282, 2017.

16. Vassilopoulou L, Psycharakis C, Petrakis D, Tsiaoussis J and Tsatsakis AM: Obesity, persistent organic pollutants and related health problems. Adv Exp Med Biol 960: 81-110, 2017.

17. Bastard JP, Maachi M, Lagathu C, Kim MJ, Caron M, Vidal H, Capeau $J$ and Feve B: Recent advances in the relationship between obesity, inflammation, and insulin resistance. Eur Cytokine Netw 17: 4-12, 2006.

18. Baltzis D, Meimeti E, Grammatikopoulou MG, Roustit M, Mavrogonatou E, Kletsas D, Efraimidou S, Manes C, Nikolouzakis TK, Tsiaoussis J, et al: Assessment of telomerase activity in leukocytes of type 2 diabetes mellitus patients having or not foot ulcer: Possible correlation with other clinical parameters. Exp Ther Med 15: 3420-3424, 2018

19. Engin AB, Tsatsakis AM, Tsoukalas D and Engin A: Do flavanols-rich natural products relieve obesity-related insulin resistance? Food Chem Toxicol 112: 157-167, 2018

20. Ungurianu A, Margină D, Grădinaru D, Băcanu C, Ilie M, Tsitsimpikou C, Tsarouhas K, Spandidos DA and Tsatsakis AM: Lipoprotein redox status evaluation as a marker of cardiovascular disease risk in patients with inflammatory disease. Mol Med Rep 15: 256-262, 2017.

21. Zimmet P, Alberti KG and Shaw J: Global and societal implications of the diabetes epidemic. Nature 414: 782-787, 2001.

22. Tilg H: The role of cytokines in non-alcoholic fatty liver disease. Dig Dis 28: 179-185, 2010.

23. Tilg $\mathrm{H}$ and Moschen AR: Adipocytokines: Mediators linking adipose tissue, inflammation and immunity. Nat Rev Immunol 6 : $772-783,2006$

24. Gomes F, Telo DF, Souza HP, Nicolau JC, Halpern A and Serrano CV Jr: Obesity and coronary artery disease: role of vascular inflammation. Arq Bras Cardiol 94: 255-266, 2010 (In English, Portuguese, Spanish).

25. Ungurianu A, Şeremet O, Gagniuc E, Olaru OT, Guţu C Grădinaru D, Ionescu-Tîrgovişte C, Margină D and Dănciulescu-Miulescu R: Preclinical and clinical results regarding the effects of a plant-based antidiabetic formulation versus well established antidiabetic molecules. Pharmacol Res 150: 104522, 2019.

26. Procaccini C, Carbone F, Galgani M, La Rocca C, De Rosa V, Cassano S and Matarese G: Obesity and susceptibility to autoimmune diseases. Expert Rev Clin Immunol 7: 287-294, 2011.

27. Denes A, Thornton P, Rothwell NJ and Allan SM: Inflammation and brain injury: Acute cerebral ischaemia, peripheral and central inflammation. Brain Behav Immun 24: 708-723, 2010.

28. Ohman MK, Wright AP, Wickenheiser KJ, Luo W and Eitzman DT: Visceral adipose tissue and atherosclerosis. Curr Vasc Pharmacol 7: 169-179, 2009.

29. Wolin KY, Carson K and Colditz GA: Obesity and cancer. Oncologist 15: 556-565, 2010.

30. Mangge H, Almer G, Truschnig-Wilders M, Schmidt A, Gasser R and Fuchs D: Inflammation, adiponectin, obesity and cardiovascular risk. Curr Med Chem 17: 4511-4520, 2010.

31. Tsoukalas D, Alegakis A, Fragkiadaki P, Papakonstantinou E, Nikitovic D, Karataraki A, Nosyrev AE, Papadakis EG, Spandidos DA, Drakoulis N, et al: Application of metabolomics: Focus on the quantification of organic acids in healthy adults. Int J Mol Med 40: 112-120, 2017.

32. Tsoukalas D, Alegakis AK, Fragkiadaki P, Papakonstantinou E, Tsilimidos G, Geraci F, Sarandi E, Nikitovic D, Spandidos DA and Tsatsakis A: Application of metabolomics part II: Focus on fatty acids and their metabolites in healthy adults. Int $\mathrm{J}$ Mol Med 43: 233-242, 2019.

33. Tsoukalas D, Fragoulakis V, Sarandi E, Docea AO, Papakonstaninou E, Tsilimidos G, Anamaterou C, Fragkiadaki P, Aschner M, Tsatsakis A, et al: Targeted metabolomic analysis of serum fatty acids for the prediction of autoimmune diseases. Front Mol Biosci 6: 120, 2019.

34. Smethers AD and Rolls BJ: Dietary management of obesity: Cornerstones of healthy eating patterns. Med Clin North Am 102: 107-124, 2018.
35. Pérez-Escamilla R, Obbagy JE, Altman JM, Essery EV, McGrane MM, Wong YP, Spahn JM and Williams CL: Dietary energy density and body weight in adults and children: A systematic review. J Acad Nutr Diet 112: 671-684, 2012

36. Arango-Angarita A, Rodríguez-Ramírez S, Serra-Majem L and Shamah-Levy T: Dietary energy density and its association with overweight or obesity in adolescents: A systematic review of observational studies. Nutrients 10 E1612, 2018.

37. Patterson E, Wärnberg J, Poortvliet E, Kearney JM and Sjöström M: Dietary energy density as a marker of dietary quality in Swedish children and adolescents: The European Youth Heart Study. Eur J Clin Nutr 64: 356-363, 2010.

38. Rouhani MH, Haghighatdoost F, Surkan PJ and Azadbakht L: Associations between dietary energy density and obesity: A systematic review and meta-analysis of observational studies. Nutrition 32: 1037-1047, 2016.

39. Sassi F, Tamone C and D'Amelio P: Vitamin D: Nutrient, hormone, and immunomodulator. Nutrients 10: E1656, 2018.

40. Lee GY and Han SN: The role of vitamin E in immunity. Nutrients 10: E1614, 2018.

41. Avery JC and Hoffmann PR: Selenium, selenoproteins, and immunity. Nutrients 10: E1203, 2018.

42. Manzel A, Muller DN, Hafler DA, Erdman SE, Linker RA and Kleinewietfeld M: Role of 'Western diet' in inflammatory autoimmune diseases. Curr Allergy Asthma Rep 14: 404, 2014.

43. Papandreou C, Schiza SE, Tzatzarakis MN, Kavalakis M, Hatzis CM, Tsatsakis AM, Kafatos AG, Siafakas NM and Tzanakis NE: Effect of Mediterranean diet on lipid peroxidation marker TBARS in obese patients with OSAHS under CPAP treatment: a randomised trial. Sleep Breath 16: 873-879, 2012.

44. Tsarouhas A, Soufla G, Tsarouhas K, Katonis P, Pasku D, Vakis A, Tsatsakis AM and Spandidos DA: Molecular profile of major growth factors in lumbar intervertebral disc herniation: Correlation with patient clinical and epidemiological characteristics. Mol Med Rep 15: 2195-2203, 2017.

45. Gradinaru D, Margina D, Borsa C, Ionescu C, Ilie M, Costache M, Dinischiotu A and Prada GI: Adiponectin: Possible link between metabolic stress and oxidative stress in the elderly. Aging Clin Exp Res 29: 621-629, 2017.

46. Gaforio JJ, Visioli F, Alarcón-de-la-Lastra C, Castañer O, Delgado-Rodríguez M, Fitó M, Hernández AF, Huertas JR, Martínez-González MA, Menendez JA, et al: Virgin olive oil and health: Summary of the III International Conference on Virgin Olive Oil and Health Consensus Report, JAEN (Spain) 2018. Nutrients 11: E2039, 2019.

47. Margina D, Ilie M and Gradinaru D: Quercetin and epigallocatechin gallate induce in vitro a dose-dependent stiffening and hyperpolarizing effect on the cell membrane of human mononuclear blood cells. Int J Mol Sci 13: 4839-4859, 2012.

48. Bischoff SC, Barbara G, Buurman W, Ockhuizen T, Schulzke JD, Serino M, Tilg H, Watson A and Wells JM: Intestinal permeability - a new target for disease prevention and therapy. BMC Gastroenterol 14: 189, 2014

49. Timmermans S, Bogie JF, Vanmierlo T, Lütjohann D, Stinissen P, Hellings $\mathrm{N}$ and Hendriks JJ: High fat diet exacerbates neuroinflammation in an animal model of multiple sclerosis by activation of the renin angiotensin system. J Neuroimmune Pharmacol 9: 209-217, 2014.

50. Jhun JY, Yoon BY, Park MK, Oh HJ, Byun JK, Lee SY, Min JK, Park SH, Kim HY and Cho ML: Obesity aggravates the joint inflammation in a collagen-induced arthritis model through deviation to Th17 differentiation. Exp Mol Med 44: 424-431, 2012.

51. Paik J, Fierce Y, Treuting PM, Brabb T and Maggio-Price L: High-fat diet-induced obesity exacerbates inflammatory bowel disease in genetically susceptible Mdrla-/- male mice. J Nutr 143: $1240-1247,2013$

52. Klack K, Bonfa E and Borba Neto EF: Diet and nutritional aspects in systemic lupus erythematosus. Rev Bras Reumatol 52: 384-408, 2012

53. De Rosa V, Procaccini C, La Cava A, Chieffi P, Nicoletti GF, Fontana S, Zappacosta S and Matarese G: Leptin neutralization interferes with pathogenic $\mathrm{T}$ cell autoreactivity in autoimmune encephalomyelitis. J Clin Invest 116: 447-455, 2006.

54. Cipolletta D, Feuerer M, Li A, Kamei N, Lee J, Shoelson SE, Benoist C and Mathis D: PPAR- $\gamma$ is a major driver of the accumulation and phenotype of adipose tissue Treg cells. Nature 486: 549-553, 2012 . 
55. Grimes CA, Bolhuis DP, He FJ and Nowson CA: Dietary sodium intake and overweight and obesity in children and adults: A protocol for a systematic review and meta-analysis. Syst Rev 5: 7, 2016

56. Savica V, Bellinghieri G and Kopple JD: The effect of nutrition on blood pressure. Annu Rev Nutr 30: 365-401, 2010.

57. Kleinewietfeld M, Manzel A, Titze J, Kvakan H, Yosef N, Linker RA, Muller DN and Hafler DA: Sodium chloride drives autoimmune disease by the induction of pathogenic TH17 cells. Nature 496: 518-522, 2013.

58. Kino T, Takatori $\mathrm{H}$, Manoli I, Wang $\mathrm{Y}$, Tiulpakov A Blackman MR, Su YA, Chrousos GP, DeCherney AH and Segars JH: Brx mediates the response of lymphocytes to osmotic stress through the activation of NFAT5. Sci Signal 2: ra5, 2009.

59. Woehrle T, Yip L, Manohar M, Sumi Y, Yao Y, Chen Y and Junger WG: Hypertonic stress regulates $\mathrm{T}$ cell function via pannexin-1 hemichannels and P2X receptors. J Leukoc Biol 88 1181-1189, 2010

60. Musso G, Gambino R and Cassader M: Interactions between gut microbiota and host metabolism predisposing to obesity and diabetes. Annu Rev Med 62: 361-380, 2011.

61. Sze MA, Dimitriu PA, Hayashi S, Elliott WM, McDonough JE Gosselink JV, Cooper J, Sin DD, Mohn WW and Hogg JC: The lung tissue microbiome in chronic obstructive pulmonary disease. Am J Respir Crit Care Med 185: 1073-1080, 2012.

62. Greenblum S, Turnbaugh PJ and Borenstein E: Metagenomic systems biology of the human gut microbiome reveals topological shifts associated with obesity and inflammatory bowel disease. Proc Natl Acad Sci USA 109: 594-599, 2012.

63. Tkacova R: Systemic inflammation in chronic obstructive pulmonary disease: May adipose tissue play a role? Review of the literature and future perspectives. Mediators Inflamm 2010 585989, 2010.

64. Jiang F, Deng L, Zhang L, Cai Y, Cheung CW and Xia Z: Review of the clinical characteristics of coronavirus disease 2019 (COVID-19). J Gen Intern Med: Mar 4, 2020 (Epub ahead of print).

65. Huang R, Zhu L, Xue L, Liu L, Yan X, Wang J, Zhang B, $\mathrm{Xu}$ T, Ji F, Zhao Y, Cheng J, et al: Clinical findings of patients with Coronavirus Disease 2019 in Jiangsu Province, China: A Retrospective, Multi-Center Study. SSRN: http://dx.doi. org/10.2139/ssrn.3548785.

66. Petrilli CM, Jones SA, Yang JJ, Rajagopalan H, O'Donnell LF, Chernyak Y, Tobin K, Cerfolio RJ, Francois F and Horwitz LI Factors associated with hospitalization and critical illness among 4,103 patients with COVID-19 disease in New York City. medRxiv: https://doi.org/10.1101/2020.04.08.20057794.

67. Miles EA, Rees D, Banerjee T, Cazzola R, Lewis S, Wood R, Oates R, Tallant A, Cestaro B, Yaqoob P, et al: Age-related increases in circulating inflammatory markers in men are independent of BMI, blood pressure and blood lipid concentrations. Atherosclerosis 196: 298-305, 2008.

68. Crooke SN, Ovsyannikova IG, Poland GA and Kennedy RB: Immunosenescence: A systems-level overview of immune cell biology and strategies for improving vaccine responses. Exp Gerontol 124: 110632, 2019.

69. Leonarduzzi G, Gamba P, Gargiulo S, Biasi F and Poli G: Inflammation-related gene expression by lipid oxidation-derived products in the progression of atherosclerosis. Free Radic Biol Med 52: 19-34, 2012.

70. Berzins SP, Uldrich AP, Sutherland JS, Gill J, Miller JF, Godfrey DI and Boyd RL: Thymic regeneration: Teaching an old immune system new tricks. Trends Mol Med 8: 469-476, 2002.

71. Maggini S, Pierre A and Calder PC: Immune function and micronutrient requirements change over the life course. Nutrients 10 : E1531, 2018.

72. Salanitro AH, Ritchie CS, Hovater M, Roth DL, Sawyer P, Locher JL, Bodner E, Brown CJ and Allman RM: Inflammatory biomarkers as predictors of hospitalization and death in community-dwelling older adults. Arch Gerontol Geriatr 54 e387-e391, 2012.

73. Wadhwa PD, Buss C, Entringer S and Swanson JM: Developmental origins of health and disease: Brief history of the approach and current focus on epigenetic mechanisms. Semin Reprod Med 27: 358-368, 2009.

74. Jirtle RL and Skinner MK: Environmental epigenomics and disease susceptibility. Nat Rev Genet 8: 253-262, 2007.

75. Evans AC, Papachristou GI and Whitcomb DC: Obesity and the risk of severe acute pancreatitis. Minerva Gastroenterol Dietol 56: 169-179, 2010
76. Alam I, Ng TP and Larbi A: Does inflammation determine whether obesity is metabolically healthy or unhealthy? The aging perspective. Mediators Inflamm 2012: 456456, 2012.

77. Sharabiani MT, Vermeulen R, Scoccianti C, Hosnijeh FS, Minelli L, Sacerdote C, Palli D, Krogh V, Tumino R, Chiodini $\mathrm{P}$, et al: Immunologic profile of excessive body weight. Biomarkers 16: 243-251, 2011.

78. Elias CF, Aschkenasi C, Lee C, Kelly J, Ahima RS, Bjorbaek C, Flier JS, Saper CB and Elmquist JK: Leptin differentially regulates NPY and POMC neurons projecting to the lateral hypothalamic area. Neuron 23: 775-786, 1999.

79. Forny-Germano L, De Felice FG and Vieira MNDN: The role of leptin and adiponectin in obesity-associated cognitive decline and Alzheimer's disease. Front Neurosci 12: 1027, 2019.

80. Honce R and Schultz-Cherry S: Impact of obesity on influenza A virus pathogenesis, immune response, and evolution. Front Immunol 10: 1071, 2019.

81. Katsikantami I, Sifakis S, Tzatzarakis MN, Vakonaki E, Kalantzi OI, Tsatsakis AM and Rizos AK: A global assessment of phthalates burden and related links to health effects. Environ Int 97: 212-236, 2016

82. Burgio E, Lopomo A and Migliore L: Obesity and diabetes: From genetics to epigenetics. Mol Biol Rep 42: 799-818, 2015.

83. Katsarou MS, Karathanasopoulou A, Andrianopoulou A, Desiniotis V, Tzinis E, Dimitrakis E, Lagiou M, Charmandari E, Aschner M, Tsatsakis AM, et al: Beta 1, Beta 2 and Beta 3 Adrenergic receptor gene polymorphisms in a Southeastern European population. Front Genet 9: 560, 2018

84. Eliakim A, Schwindt C, Zaldivar F, Casali P and Cooper DM: Reduced tetanus antibody titers in overweight children. Autoimmunity 39: 137-141, 2006.

85. Neuendorf R, Corn J, Hanes D and Bradley R: Impact of food immunoglobulin G-based elimination diet on subsequent food immunoglobulin $\mathrm{G}$ and quality of life in overweight/obese adults. J Altern Complement Med 25: 241-248, 2019.

86. Poutahidis T, Kleinewietfeld M, Smillie C, Levkovich T, Perrotta A, Bhela S, Varian BJ, Ibrahim YM, Lakritz JR, Kearney SM, et al: Microbial reprogramming inhibits Western diet-associated obesity. PLoS One 8: e68596, 2013.

87. Winer S, Paltser G, Chan Y, Tsui H, Engleman E, Winer D and Dosch HM: Obesity predisposes to Th17 bias. Eur J Immunol 39: 2629-2635, 2009

88. Skalny AV, Rink L, Ajsuvakova OP, Aschner M, Gritsenko VA, Alekseenko SI, Svistunov AA, Petrakis D, Spandidos DA, Aaseth J, et al: Zinc and respiratory tract infections: Perspectives for COVID-19 (Review). Int J Mol Med: Apr 14, 2020 (Epub ahead of print).

89. Sumarac-Dumanovic M, Stevanovic D, Ljubic A, Jorga J, Simic M, Stamenkovic-Pejkovic D, Starcevic V, Trajkovic V and Micic D: Increased activity of interleukin-23/interleukin-17 proinflammatory axis in obese women. Int J Obes 33: 151-156, 2009.

90. Kahn SE, Zinman B, Haffner SM, O'Neill MC, Kravitz BG, Yu D, Freed MI, Herman WH, Holman RR, Jones NP, et al; ADOPT Study Group: Obesity is a major determinant of the association of C-reactive protein levels and the metabolic syndrome in type 2 diabetes. Diabetes 55: 2357-2364, 2006.

91. Wittekindt $\mathrm{OH}$ : Tight junctions in pulmonary epithelia during lung inflammation. Pflugers Arch 469: 135-147, 2017.

92. Ahmed M and Gaffen SL: IL-17 in obesity and adipogenesis. Cytokine Growth Factor Rev 21: 449-453, 2010.

93. Zambrano-Zaragoza JF, Romo-Martínez EJ, Durán-Avelar MJ, García-Magallanes N and Vibanco-Pérez N: Th17 cells in autoimmune and infectious diseases. Int J Inflamm 2014: 651503, 2014.

94. Bermejo-Martin JF, Ortiz de Lejarazu R, Pumarola T, Rello J, Almansa R, Ramírez P, Martin-Loeches I, Varillas D, Gallegos MC, Serón C, et al: Th1 and Th17 hypercytokinemia as early host response signature in severe pandemic influenza. Crit Care 13: R201, 2009.

95. Strissel KJ, DeFuria J, Shaul ME, Bennett G, Greenberg AS and Obin MS: T-cell recruitment and Th1 polarization in adipose tissue during diet-induced obesity in C57BL/6 mice. Obesity (Silver Spring) 18: 1918-1925, 2010.

96. Zhou Y, Fu B, Zheng X, Wang D, Zhao C, Qi Y, Sun R, Tian Z, $\mathrm{Xu} \mathrm{X}$ and Wei H: Pathogenic T cells and inflammatory monocytes incite inflammatory storm in severe COVID-19 patients. Natl Sci Rev: doi:10.1093/nsr/nwaa041.

97. Fang L, Karakiulakis G and Roth M: Are patients with hypertension and diabetes mellitus at increased risk for COVID-19 infection? Lancet Respir Med 8: e21, 2020. 
98.Favalli EG, Ingegnoli F, De Lucia O, Cincinelli G, Cimaz R and Caporali R: COVID-19 infection and rheumatoid arthritis Faraway, so close! Autoimmun Rev 19: 102523, 2020.

99. Andersen LB, Przybyl L, Haase N, von Versen-Höynck F Qadri F, Jørgensen JS, Sorensen GL, Fruekilde P, Poglitsch M, Szijarto I, et al: Vitamin D depletion aggravates hypertension and target-organ damage. J Am Heart Assoc 4: e001417, 2015.

100. Santos RA, Ferreira AJ, Verano-Braga T and Bader $M$ : Angiotensin-converting enzyme 2, angiotensin-(1-7) and Mas: New players of the renin-angiotensin system. J Endocrinol 216 R1-R17, 2013.

101. Ames BN: Prolonging healthy aging: Longevity vitamins and proteins. Proc Natl Acad Sci USA 115: 10836-10844, 2018.

102. Costa C, Tsatsakis A, Mamoulakis C, Teodoro M, Briguglio G, Caruso E, Tsoukalas D, Margina D, Dardiotis E, Kouretas D, et al: Current evidence on the effect of dietary polyphenols intake on chronic diseases. Food Chem Toxicol 110: 286-299, 2017.

103. Hernandez JP, Mota LC and Baldwin WS: Activation of CAR and PXR by dietary, environmental and occupational chemicals alters drug metabolism, intermediary metabolism, and cell proliferation. Curr Pharmacogenomics Person Med 7: 81-105, 2009.

104. Krzyżowska M, Wincenciak M, Winnicka A, Baranowski A, Jaszczak K, Zimny J and Niemiałtowski M: The effect of multigenerational diet containing genetically modified triticale on immune system in mice. Pol J Vet Sci 13: 423-430, 2010.

105.Lack G: Clinical risk assessment of GM foods. Toxicol Lett 127 337-340, 2002.

106. van Herpen NA and Schrauwen-Hinderling VB: Lipid accumulation in non-adipose tissue and lipotoxicity. Physiol Behav 94 231-241, 2008.

107.Li C, Ford ES, Mokdad AH, Balluz LS, Brown DW and Giles WH: Clustering of cardiovascular disease risk factors and health-related quality of life among US adults. Value Health 11: 689-699, 2008.

108. Garbarino J and Sturley SL: Saturated with fat: New perspectives on lipotoxicity. Curr Opin Clin Nutr Metab Care 12: 110-116, 2009.

109. Bosma M, Kersten S, Hesselink MK and Schrauwen P Re-evaluating lipotoxic triggers in skeletal muscle: Relating intramyocellular lipid metabolism to insulin sensitivity. Prog Lipid Res 51: 36-49, 2012.

110. Unger RH and Scherer PE: Gluttony, sloth and the metabolic syndrome: A roadmap to lipotoxicity. Trends Endocrinol Metab 21: 345-352, 2010.

111. Sies H (ed): Oxidative Stress. 1st edition. Academic Press, 1985.

112. Jones DP: Redefining oxidative stress. Antioxid Redox Signal 8: 1865-1879, 2006

113. Benedetti A, Comporti $\mathrm{M}$ and Esterbauer H: Identification of 4-hydroxynonenal as a cytotoxic product originating from the peroxidation of liver microsomal lipids. Biochim Biophys Acta 620: 281-296, 1980

114. Hauck AK and Bernlohr DA: Oxidative stress and lipotoxicity. J Lipid Res 57: 1976-1986, 2016.

115. Barrera G, Pizzimenti S, Ciamporcero ES, Daga M, Ullio C Arcaro A, Cetrangolo GP, Ferretti C, Dianzani C, Lepore A and Gentile F: Role of 4-hydroxynonenal-protein adducts in human diseases. Antioxid Redox Signal 22: 1681-1702, 2015.

116. Grimsrud PA, Picklo MJ Sr, Griffin TJ and Bernlohr DA Carbonylation of adipose proteins in obesity and insulin resistance: Identification of adipocyte fatty acid-binding protein as a cellular target of 4-hydroxynonenal. Mol Cell Proteomics 6 624-637, 2007.

117. Wagner TM, Mullally JE and Fitzpatrick FA: Reactive lipid species from cyclooxygenase-2 inactivate tumor suppressor LKB1/STK11: Cyclopentenone prostaglandins and 4-hydroxy-2-nonenal covalently modify and inhibit the AMP-kinase kinase that modulates cellular energy homeostasis and protein translation. J Biol Chem 281: 2598-2604, 2006.

118. Barreiro E, del Puerto-Nevado L, Puig-Vilanova E, Pérez-Rial S, Sánchez F, Martínez-Galán L, Rivera S, Gea J, González-Mangado N and Peces-Barba G: Cigarette smoke-induced oxidative stress in skeletal muscles of mice. Respir Physiol Neurobiol 182: 9-17, 2012.

119. Castegna A, Aksenov M, Aksenova M, Thongboonkerd V Klein JB, Pierce WM, Booze R, Markesbery WR and Butterfield DA: Proteomic identification of oxidatively modified proteins in Alzheimer's disease brain. Part I: Creatine kinase $\mathrm{BB}$, glutamine synthase, and ubiquitin carboxy-terminal hydrolase L-1. Free Radic Biol Med 33: 562-571, 2002.
120. Dalle-Donne I, Rossi R, Giustarini D, Milzani A and Colombo R: Protein carbonyl groups as biomarkers of oxidative stress. Clin Chim Acta 329: 23-38, 2003

121.Pirinccioglu AG, Gökalp D, Pirinccioglu M, Kizil G and Kizil M: Malondialdehyde (MDA) and protein carbonyl (PCO) levels as biomarkers of oxidative stress in subjects with familial hypercholesterolemia. Clin Biochem 43: 1220-1224, 2010.

122.Leonarduzzi G, Chiarpotto E, Biasi F and Poli G 4-Hydroxynonenal and cholesterol oxidation products in atherosclerosis. Mol Nutr Food Res 49: 1044-1049, 2005.

123.Zarkovic K: 4-hydroxynonenal and neurodegenerative diseases. Mol Aspects Med 24: 293-303, 2003

124. Kassir R: Risk of COVID-19 for patients with obesity. Obes Rev: Apr 13, 2020 (Epub ahead of print).

125.Zhu Y, Ren C, Zhang M and Zhong Y: Perilipin 5 reduces oxidative damage associated with lipotoxicity by activating the $\mathrm{PI} 3 \mathrm{~K} / \mathrm{ERK}$-mediated Nrf2-ARE signaling pathway in INS-1 pancreatic $\beta$-cells. Front Endocrinol (Lausanne) 11: 166, 2020.

126. Misumi I, Starmer J, Uchimura T, Beck MA, Magnuson T and Whitmire JK: Obesity expands a distinct population of T cells in adipose tissue and increases vulnerability to infection. Cell Rep 27: 514-524.e5, 2019

127. Bourgeois C, Gorwood J, Barrail-Tran A, Lagathu C, Capeau J, Desjardins D, Le Grand R, Damouche A, Béréziat V and Lambotte O: Specific biological features of adipose tissue, and their impact on HIV persistence. Front Microbiol 10: 2837, 2019.

128. Ryan PM and Caplice NM: Is adipose tissue a reservoir for viral spread, immune activation and cytokine amplification in COVID-19. Obesity (Silver Spring): Apr 21, 2020 (Epub ahead of print).

129. Venkata C, Sampathkumar P and Afessa B: Hospitalized patients with 2009 H1N1 influenza infection: The Mayo Clinic experience. Mayo Clin Proc 85: 798-805, 2010.

130. Louie JK, Acosta M, Winter K, Jean C, Gavali S, Schechter R, Vugia D, Harriman K, Matyas B, Glaser CA, et al; California Pandemic (H1N1) Working Group: Factors associated with death or hospitalization due to pandemic 2009 influenza A(H1N1) infection in California. JAMA 302: 1896-1902, 2009.

131. Thompson DL, Jungk J, Hancock E, Smelser C, Landen M, Nichols M, Selvage D, Baumbach J and Sewell M: Risk factors for 2009 pandemic influenza A (H1N1)-related hospitalization and death among racial/ethnic groups in New Mexico. Am J Public Health 101: 1776-1784, 2011.

132. Dietz W and Santos-Burgoa C: Obesity and its implications for COVID-19 mortality. Obesity (Silver Spring): Apr 1, 2020 (Epub ahead of print)

133. Sun Y, Wang Q, Yang G, Lin C, Zhang Y and Yang P: Weight and prognosis for influenza $\mathrm{A}(\mathrm{H} 1 \mathrm{~N} 1) \mathrm{pdm} 09$ infection during the pandemic period between 2009 and 2011: A systematic review of observational studies with meta-analysis. Infect Dis (Lond) 48: 813-822, 2016.

134. Liu M, He P, Liu HG, Wang XJ, Li FJ, Chen S, Lin J, Chen P, Liu JH and Li CH: Clinical characteristics of 30 medical workers infected with new coronavirus pneumonia. Zhonghua Jie He He Hu Xi Za Zhi 43: E016, 2020 (In Chinese).

135. Peng YD, Meng K, Guan HQ, Leng L, Zhu RR, Wang BY, He MA, Cheng LX, Huang K and Zeng QT: Clinical characteristics and outcomes of 112 cardiovascular disease patients infected by 2019-nCoV. Zhonghua Xin Xue Guan Bing Za Zhi 48: E004, 2020 (In Chinese).

136. Verdecchia P, Cavallini C, Spanevello A and Angeli F: The pivotal link between ACE2 deficiency and SARS-CoV-2 infection. Eur J Intern Med: Apr 20, 2020 (Epub ahead of print).

137. Hoffmann M, Kleine-Weber H, Schroeder S, Krüger N, Herrler T, Erichsen S, Schiergens TS, Herrler G, Wu NH, Nitsche A, et al: SARS-CoV-2 cell entry depends on ACE2 and TMPRSS2 and is blocked by a clinically proven protease inhibitor. Cell 181: 271-280.e8, 2020.

138. Hussain M, Jabeen N, Raza F, Shabbir S, Baig AA, Amanullah A and Aziz B: Structural variations in human ACE2 may influence its binding with SARS-CoV-2 spike protein. J Med Virol: Apr 6, 2020 (Epub ahead of print).

139. Santos RA and Ferreira AJ: Angiotensin-(1-7) and the renin-angiotensin system. Curr Opin Nephrol Hypertens 16 : $122-128,2007$.

140. Cavalera M, Wang J and Frangogiannis NG: Obesity, metabolic dysfunction, and cardiac fibrosis: Pathophysiological pathways, molecular mechanisms, and therapeutic opportunities. Transl Res 164: 323-335, 2014 
141. Senador D, Kanakamedala K, Irigoyen MC, Morris M and Elased KM: Cardiovascular and autonomic phenotype of $\mathrm{db} / \mathrm{db}$ diabetic mice. Exp Physiol 94: 648-658, 2009.

142. Alpert MA, Omran J, Mehra A and Ardhanari S: Impact of obesity and weight loss on cardiac performance and morphology in adults. Prog Cardiovasc Dis 56: 391-400, 2014.

143. Touyz RM, Savoia C, He Y, Endemann D, Pu Q, Ko EA, Deciuceis C, Montezano A and Schiffrin EL: Increased inflammatory biomarkers in hypertensive type 2 diabetic patients: Improvement after angiotensin II type 1 receptor blockade. J Am Soc Hypertens 1: 189-199, 2007.

144. Lumeng CN and Saltiel AR: Inflammatory links between obesity and metabolic disease. J Clin Invest 121: 2111-2117, 2011

145. World Health Organization (WHO): Advice on the use of masks in the context of COVID-19: interim guidance, 6 April 2020. WHO, Geneva, 2020.

146. World Health Organization (WHO): Rational use of personal protective equipment for coronavirus disease (COVID-19) and considerations during severe shortages: interim guidance, 6 April 2020. WHO, Geneva, 2020.

147. Marcus Y, Shefer G and Stern N: Adipose tissue renin-angiotensin-aldosterone system (RAAS) and progression of insulin resistance. Mol Cell Endocrinol 378: 1-14, 2013.

148. Jose RJ and Manuel A: Does COVID-19 disprove the obesity paradox in ARDS? Obesity (Silver Spring): Apr 15, 2020 (Epub ahead of print).

149. O'Brien JM Jr, Phillips GS, Ali NA, Lucarelli M, Marsh CB and Lemeshow S: Body mass index is independently associated with hospital mortality in mechanically ventilated adults with acute lung injury. Crit Care Med 34: 738-744, 2006.

150. Fernandez-Bustamante A and Repine J: Adipose-lung cell crosstalk in the obesity-ARDS paradox. J Pulm Respir Med 3: $144,2013$.

151.Nie W, Zhang Y, Jee SH, Jung KJ, Li B and Xiu Q: Obesity survival paradox in pneumonia: A meta-analysis. BMC Med 12: $61,2014$.

152. Stefan N, Birkenfeld AL, Schulze MB and Ludwig DS: Obesity and impaired metabolic health in patients with COVID-19. Nat Rev Endocrinol: Apr 23, 2020 (Epub ahead of print).

153. Akoumianakis I, Akawi N and Antoniades C: Exploring the crosstalk between adipose tissue and the cardiovascular system. Korean Circ J 47: 670-685, 2017.

154. Simonnet A, Chetboun M, Poissy J, Raverdy V, Noulette J, Duhamel A, Labreuche J, Mathieu D, Pattou F and Jourdain M; Lille Intensive Care COVID-19 and Obesity study group: High prevalence of obesity in severe acute respiratory syndrome coronavirus-2 (SARS-CoV-2) requiring invasive mechanical ventilation. Obesity (Silver Spring): Apr 9, 2020 (Epub ahead of print)

155.Lighter J, Phillips M, Hochman S, Sterling S, Johnson D, Francois $\mathrm{F}$ and Stachel A: Obesity in patients younger than 60 years is a risk factor for Covid-19 hospital admission. Clin Infect Dis ciaa415, 2020

156.Lederman MM: Cell-mediated immunity and pregnancy. Chest 86 (Suppl 3): 6S-9S, 1984.

157. Harris JW: Influenza occurring in pregnant women: a statistical study of thirteen hundred and fifty cases. JAMA 72: 978-980, 1919
158. Greenberg M, Jacobziner H, Pakter J and Weisl BA: Maternal mortality in the epidemic of Asian influenza, New York City, 1957. Am J Obstet Gynecol 76: 897-902, 1958.

159. Klein SL, Passaretti C, Anker M, Olukoya P and Pekosz A: The impact of sex, gender and pregnancy on 2009 H1N1 disease. Biol Sex Differ 1: 5, 2010.

160. Harger JH, Ernest JM, Thurnau GR, Moawad A, Momirova V, Landon MB, Paul R, Miodovnik M, Dombrowski M, Sibai B, et al; National Institute of Child Health and Human Development, Network of Maternal-Fetal Medicine Units: Risk factors and outcome of varicella-zoster virus pneumonia in pregnant women. J Infect Dis 185: 422-427, 2002.

161. Braden CR: Listeriosis. Pediatr Infect Dis J 22: 745-746, 2003.

162. Shulman CE and Dorman EK: Importance and prevention of malaria in pregnancy. Trans R Soc Trop Med Hyg 97: 30-35, 2003.

163. Stockman LJ, Lowther SA, Coy K, Saw J and Parashar UD: SARS during pregnancy, United States. Emerg Infect Dis 10 1689-1690, 2004.

164. Neuzil KM, Reed GW, Mitchel EF, Simonsen L and Griffin MR: Impact of influenza on acute cardiopulmonary hospitalizations in pregnant women. Am J Epidemiol 148: 1094-1102, 1998.

165.Irving WL, James DK, Stephenson T, Laing P, Jameson C, Oxford JS, Chakraverty P, Brown DW, Boon AC and Zambon MC: Influenza virus infection in the second and third trimesters of pregnancy: A clinical and seroepidemiological study. BJOG 107: 1282-1289, 2000.

166. Moynihan AT, Hehir MP, Glavey SV, Smith TJ and Morrison JJ: Inhibitory effect of leptin on human uterine contractility in vitro. Am J Obstet Gynecol 195: 504-509, 2006

167. Mor G and Cardenas I: The immune system in pregnancy: A unique complexity. Am J Reprod Immunol 63: 425-433, 2010.

168. Kraus TA, Engel SM, Sperling RS, Kellerman L, Lo Y Wallenstein S, Escribese MM, Garrido JL, Singh T, Loubeau M, et al: Characterizing the pregnancy immune phenotype: Results of the viral immunity and pregnancy (VIP) study. J Clin Immunol 32: 300-311, 2012.

169. Rodríguez-García M, Oliva H, Climent N, García F, Gatell JM and Gallart T: Human immature monocyte-derived dendritic cells produce and secrete alpha-defensins 1-3. J Leukoc Biol 82: 1143-1146, 2007.

170. Wegmann TG, Lin H, Guilbert L and Mosmann TR: Bidirectional cytokine interactions in the maternal-fetal relationship: Is successful pregnancy a TH2 phenomenon? Immunol Today 14: 353-356, 1993

171. White SH, Wimley WC and Selsted ME: Structure, function, and membrane integration of defensins. Curr Opin Struct Biol 5: $521-527,1995$.

This work is licensed under a Creative Commons Attribution-NonCommercial-NoDerivatives 4.0 International (CC BY-NC-ND 4.0) License. 